\title{
Taking on the Creationists
}

\section{Philip Kitcher}

Science and Creationism. Edited by Ashley Montagu.

Oxford University Press: 1984. Pp.415. Hbk £22; pbk \$9.95.

ON 5 January 1982, William Overton, justice in the Eastern Arkansas district of the United States District Court, delivered his decision in the case of Maclean versus the Arkansas Board of Education: "The relief prayed for is granted". So ended another phase in the long history of controversy about evolutionary biology and its place in science education. The attempt to introduce so-called "Creation science" into the American high-school biology curriculum by law foundered on the rock of Overton's decision. Much relieved, the prominent scientists who had led the resistance could return to work.

Two years and several volumes later, we have a new anthology, with nineteen articles, an editorial introduction and a historical preface. It is natural to wonder whether there is a niche for Ashley Montagu's collection to fill. True, Montagu reprints several pieces that are worth reading: Overton's decision, Roger Lewin's account of the notorious Arkansas Act 590 (which serves as the historical preface), and popular articles by Stephen Jay Gould and Isaac Asimov. It also contains some amusing celebrations of the great victory in Little Rock (by Michael Ruse and Gene Lyons, respectively). Yet, the question remains: is there a need for another volume on Creationism?

In my judgement, the answer is "Yes". Opposition to evolution and to the teaching of evolution continues in the United States, its traditional haven, and the Institute for Creation Research periodically claims that it is making headway elsewhere (notably in Britain and Scandinavia). Creationists seem to have returned to their favourite tactics - ambushes of local educators and assaults on textbook publishers. Until there is a body of literature that makes clear to those who make educational decisions, and to the public they represent, the magnificent accomplishment of Darwin and his successors, we shall need people to write about Creationism. Any anthology that promotes broad understanding of the overwhelming evidence for evolution and the blunders, distortions and pretences of "Creation science" should be welcome.

Unfortunately, Montagu's anthology fails to respond to the genuine need. It is a curious mixture. Relatively technical articles sit cheek-by-jowl with popular pieces, historical narratives are joined with sociological speculations and personal reminiscences. But it would be wrong to think of the book as a multi-faceted account, combining the insights of many disciplines in a systematic way. There is nothing systematic about it. What we have is a loose collection of essays that do not gain through juxtaposition.

Still, the volume contains some good material. Besides the essays to which I have already referred, there is a characteristically informative introduction by Montagu

\section{What was at stake in Little Rock?}

The principal requirement of Act 590, passed by the Arkansas State Legislature in March 1981 and declared to be unconstitutional in January 1982 because it violated the separation of church and state, was that: "public schools within this state shall give balanced treatment to creationscience and to evolution-science. Balanced treatment of these two models shall be given in classroom lectures and in textbook materials taken as a whole for each course, and in library materials and other educational programs".

"Creation science" was defined as the scientific evidence for creation, and inferences from that evidence, indicating: - Sudden creation of the Universe, energy and life from nothing.

- The insufficiency of mutation and natural selection in bringing about development of all living kinds from a single organism.

- Changes only within fixed limits of originally-created kinds of plants and animals.

- Separate ancestry for man and apes.

- Explanation of the Earth's geology by catastrophism, including the occurrence of a worldwide flood.

- A relatively recent inception of the Earth and living kinds.

and a brief, but intriguing, article by Gunther Stent, who argues that Creationism may do some good if it trims the excesses of “hyperevolutionism", represented most prominently by trends in human sociobiology. Two of the most diligent antiCreationists contribute excellent essays. Laurie Godfrey's article (a revised version of a piece that originally appeared in Natural History) provides a lucid exposé of Creationist scavenging. Godfrey demonstrates how the words of scientists are ripped out of context and hammered into weapons that Creationists can use in debate. Even more valuable is Kenneth Miller's patient and comprehensive reply to Creationist arguments about radiometric dating and the character of the fossil record. Those who pray for public understanding of the Creation-evolution controversy could hardly ask for more than that Miller's article will be widely read. Its remarkable clarity should enable anyone to appreciate the important points at issue and should show the scientific community how to take on the Creationists and win.

However unsystematic, an anthology whose articles were all of such calibre would be worth reading. This is not the case with the present collection. Indeed, some of the articles in it are likely to provide grist for Creationist mills. Robert RootBernstein tries to resolve the Creationism controversy with some muddled philosophy of science, apparently fashioned from trying to synthesize incompatible points of view. Kenneth Boulding addresses the difficult issues surrounding the compatibility of evolution and theism, but the conclusions he is led to in his speculative explorations are hardly likely to satisfy those theists who take their science seriously. Beverly Halstead has a shorter way with such questions. Creationists will have a field day with Halstead's blunt professions of scientific atheism and atheistic science. The pity of it is that the methodological and theological questions are indeed central to the Creation-evolution controversy. In dealing with them in so amateurish a fashion, this anthology does them and the scientific community a disservice.

One other article deserves special mention, Sydney Fox's detailed and technical review of "origin of life" experiments. Those readers for whom Gould, Asimov, Miller, Godfrey and many of the others write, will find this article impenetrable. Nonetheless, by showing in detail what can be achieved in the synthesis of biologically significant molecules, Fox disposes of a source of familiar Creationist objections. Yet we ought to ask if this is the right kind of response. Evolutionary theory is surely stronger today because of ingenious experiments in Florida and careful excavations in East Africa. But the theory has been taught in schools around the world for a long time, and it has been right to teach it because of the strength of the long-standing evidence in its favour. It is surely wrong to think of Fox and Leakey as shoring up a tottering edifice.

Perhaps the public needs less information about current research and more straightforward exposition of the reasons why Biblical Creationism was rejected long before Darwin and why Darwin and his contemporaries accepted descent with modification. Some of the contributors to this volume begin the necessary work, but to carry it out effectively would require a much more disciplined book. author of Abusing Science: The Case Against Creationism (MIT Press, 1982). 